\title{
Land Levelling and Its Temporal Variability under Different Levelling, Cultivation Practices and Irrigation Methods for Paddy
}

\author{
Ravindra Yaligar*, P. Balakrishnan, U. Satishkumar, P. S. Kanannavar, \\ A. S. Halepyati, M. L. Jat and N. L. Rajesh \\ Department of Soil and Water Engineering, College of Agricultural Engineering, University of \\ Agricultural Sciences (UAS) Raichur, Karnataka, India \\ *Corresponding author
}

\section{A B S T R A C T}

The field experiments were conducted in the farmers field under the jurisdiction of the University of Agricultural Sciences (UAS) Raichur during the kharif 2015 and kharif 2016 using randomized complete block design with 7 treatments to determine the effects Land

\section{Keywords}

Direct seeded rice (DSR), Laser levelling, transplanted rice (TPR), Levelling Index (LI)

Article Info

Accepted:

25 August 2017

Available Online:

10 September 2017 levelling and its temporal variability under different levelling, cultivation practices and irrigation methods for paddy. Contour analysis showed that the number of contours drawn with Surfer Software for 2-cm contour interval for the plots after laser levelling were reduced considerably and the contours were almost parallel in laser land levelling cases. The levelling indices (LI) and range of grid elevations were very small in these cases indicating very high quality and precision of land levelling works with least deterioration of topographic conditions compared to conventional levelling. Whereas, these values were more for conventional levelling due to more number and irregular pattern of contour lines, which revealed poor quality and precision of land levelling as it depended on driver's judgement. Smaller values of LI indicated higher accuracy of grading in laser levelled fields with evenly levelled topography of land and uniform distribution of water and its storage. There were changes in topographic conditions, levelling quality and precision in terms of levelling indices and range of grid elevations, over the period of study due to the influence of cultivation practices, different land levelling, irrigation methods and climatic conditions. These changes were less as indicated by 75.40 and 87.25 per cent reduction in LI in case of laser levelling methods as compared to 3.27 and 1.73 per cent increase in LI in conventional levelling methods.

\section{Introduction}

Precise land levelling of agricultural land with Laser technology is comparatively a recent resource-conservation technology (RCT) initiative in India in general and in Karnataka in particular. Paddy is the important and major food crop of the North-eastern Karnataka including Raichur region. The studies carried out on the effect of laserguided land levelling with flood irrigation in case of rice regarding water saving and enhancement of yields in the country is comparatively more. However, the novel method of paddy cultivation using drip irrigation has not been tried except some sporadic attempts in India. Thus, there is an urgent need to enhance productivity and water use efficiency of paddy through RCTs and tap and extend the potential benefits of laser land 
levelling with suitability of drip irrigation under dry DSR system of rice cultivation and to optimize the water levels with higher production.

Land development is one of the prime components of precision farming in paddy. Unevenness of paddy fields leads to the inefficient use of irrigation water, which in turn reduces the yield and farm income. Levelling index, which is a dynamic factor, determines the quality and accuracy of land levelling. Therefore, A comparative evaluation of quality and precision of levelling as affected by different land levelling methods (laser land levelling, traditional land levelling), cultivation practices (TPR and DSR) and irrigation methods (Drip and flood) and its temporal variability in paddy production during 2015 and 2016 was undertaken.

\section{Materials and Methods}

The experiment was carried out in farmer's field located at Govinadoddi village in Manvi taluka of Raichur district under the jurisdiction of the UAS Raichur during kharif 2015 and kharif 2016 using randomized complete block design with 7 treatments which were replicated thrice. The treatments included the land levelling methods viz., laser levelling with near table top level or zero per cent slope and conventional levelling, cultivation practices viz., transplanted rice (TPR) and direct seeded rice (DSR) and irrigation methods viz., drip and flood irrigation. The treatments included the land levelling methods viz., laser levelling with near table top level or zero per cent slope and conventional levelling, cultivation practices viz., transplanted rice (TPR) and direct seeded rice (DSR) and irrigation methods viz., drip and flood irrigation. The treatments were viz., $\mathrm{T}_{1}$ - Dry direct seeded rice (DSR) with laser land levelling and surface drip irrigation with $80 \mathrm{~cm}$ lateral spacing, $\mathrm{T}_{2}$ - Dry direct seeded rice with laser land levelling and surface drip irrigation with $60 \mathrm{~cm}$ lateral spacing, $\mathrm{T}_{3}$ - Dry direct seeded rice with laser land levelling and subsurface drip irrigation with $60 \mathrm{~cm}$ lateral spacing, $\mathrm{T}_{4}$ - Dry direct seeded rice with laser land levelling and subsurface drip irrigation with $80 \mathrm{~cm}$ lateral spacing, $\mathrm{T}_{5}$ - Transplanted rice (TPR) with laser land levelling and conventional method of flood irrigation, $\mathrm{T}_{6}$ Dry direct seeded rice with conventional land levelling and conventional method of flood irrigation and $\mathrm{T}_{7}$ - Control (transplanted rice with conventional land levelling using flood irrigation) i.e., farmer's practice. The paddy variety BPT - 5204 popularly known as Sona Masuri (145-150 days duration) was used as the test crop. The Diagram showing thematic flow chart of laser levelling concept is given in Fig.1. The main levelling parameter considered for study of temporal variability was levelling index.

\section{Levelling index}

The quantity and quality of the land levelling should be known before and to the irrigator for better planning of the surface irrigation systems. The land levelling quality should quantitatively reflect the precision of the field levelling. The precision of the land levelling may depend upon the volume of the earthwork in the cut or fill with reference to the desired plane in an area. The term 'levelling index' (LI) is used to represent levelling quality quantitatively.

Agarwal and Goel (1981) defined the levelling index as the average numerical variation between the proposed or designed levels and existing average field levels either before or after the completion of levelling work. It may be expressed as

Levellingindex $=\frac{\sum \text { Numericaldifferencebetween thedesignedand existinggridlevels }}{\text { Number of grid points }}$

Eq.1 
The upper limit of levelling index is zero which can be achieved only in a perfectly levelled field. Increased values of levelling index reduce the irrigation efficiency. It is, therefore, essential to assess quantitatively the effect of land levelling index on irrigation efficiency. The levelling index of the fields before and after levelling is calculated using the above equation given by Agarwal and Goel.

\section{Results and Discussion}

The data on Topographic particulars of selected field and Temporal variability of quality of land levelling (LI and Range) in all treatments as influenced by different cultivation practices, levelling methods and irrigation methods for paddy are presented in Tables 1 and 2.

Quality and precision of levelling as affected by different land levelling methods (laser land levelling, traditional land levelling), cultivation practices (TPR and DSR) and irrigation methods (Drip and flood) and its temporal variability in paddy production during 2015 and 2016 revealed that during the year 2015, before levelling, the levelling indices and range of grid elevations for $T_{1}$ to $\mathrm{T}_{4}$ were 6.10 and -16 to $12 \mathrm{~cm}$, for $\mathrm{T}_{5}$ were 6.20 and -16 to $19 \mathrm{~cm}$, for $\mathrm{T}_{6}$ the same were 6.11 and -9 to $13 \mathrm{~cm}$ and for $\mathrm{T}_{7}$ were 6.33 and -9 to $13 \mathrm{~cm}$, respectively. The levelling indices and range values of grid elevations, for all the plots before levelling indicated almost the same field topographic conditions at the start of the experiment. After laser land levelling during 2015, levelling indices and range of grid elevations for $T_{1}$ to $T_{4}$ were changed to 1.02 and -1 to $2 \mathrm{~cm}$, respectively. Similarly for $T_{5}$, the same were 1.04 and -2 to $1 \mathrm{~cm}$. After conventional levelling during 2015, levelling index (LI) and range of grid elevations for $\mathrm{T}_{6}$ were 4.00 and -8 to $8 \mathrm{~cm}$ and for $\mathrm{T}_{7}$ they were 4.00 and -8 to $8 \mathrm{~cm}$ respectively. After harvesting of paddy during 2016 the levelling indices in drip irrigated treatments with DSR, $\mathrm{T}_{1}$ to $\mathrm{T}_{4}$ changed to 4.60 $\mathrm{cm}$ with 75.40 per cent reduction, in flood irrigation with TPR $\left(\mathrm{T}_{5}\right)$ LI changed to 5.41 $\mathrm{cm}$ with 87.25 per cent reduction. Due to conventional levelling, in plots with flood irrigation and DSR i.e. $\mathrm{T}_{6}$, $\mathrm{LI}$ varied to 6.31 $\mathrm{cm}$ with 3.27 per cent increase. Also, in plots with flood irrigation and TPR i.e. $\mathrm{T}_{7}$, LI changed to $6.44 \mathrm{~cm}$ with 1.73 per cent increase.

Laser land levelling methods recorded more reduction in LI compared to traditional levelling method. Small range values of -1 to $2 \mathrm{~cm}$ and -2 to $1 \mathrm{~cm}$ were observed in $T_{1}$ to $T_{4}$ and $\mathrm{T}_{5}$ respectively against -8 to $8 \mathrm{~cm}$ and -6 to $7 \mathrm{~cm}$ in case of conventional levelled plots $\mathrm{T}_{6}$ to $\mathrm{T}_{7}$. The highest per cent reduction of LI and smaller range values of grid elevations observed in laser levelled fields indicated better quality and precision of levelling when compared to conventional method of levelling. This was due to the fact that conventional levelling purely depends on driver's judgment and skill without the help of any mechanism for achieving precision.

Table.1 Topographic particulars of selected field

\begin{tabular}{|l|l|l|l|l|l|}
\hline Sl. No. & Parameters & $\mathbf{T}_{\mathbf{1}}$ to $\mathbf{T}_{\mathbf{4}}$ & $\mathbf{T}_{\mathbf{5}}$ & $\mathbf{T}_{\mathbf{6}}$ & $\mathbf{T}_{\mathbf{7}}$ \\
\hline 1 & Length of the field $(\mathrm{m})$ & 76.20 & 78.00 & 23.50 & 23.50 \\
\hline 2 & Width of the field $(\mathrm{m})$ & 43.50 & 60.00 & 21.00 & 21.00 \\
\hline 3 & Area of the field $\left(\mathrm{m}^{\mathbf{2}}\right)$ & 3314.70 & 4680.0 & 493.50 & 493.50 \\
\hline 4 & Range of elevation $(\mathrm{cm})$ & -16 to 12 & -16 to 19 & -9 to 13 & -9 to 13 \\
\hline
\end{tabular}


Table.2 Temporal variability of quality of land levelling (LI and Range) in all treatments as influenced by different cultivation practices, levelling methods and irrigation methods for paddy

\begin{tabular}{|c|c|c|c|c|c|c|c|}
\hline \multirow{2}{*}{ Treatment } & \multirow[t]{2}{*}{ Year } & \multicolumn{2}{|c|}{2015} & \multicolumn{3}{|c|}{2016} & \multirow{2}{*}{$\begin{array}{c}\text { Change in LI } \\
2015 \text { to } 2016(\%)\end{array}$} \\
\hline & & $\mathrm{LI}(\mathbf{c m})$ & Range (cm) & & $\mathrm{LI}(\mathbf{c m})$ & Range (cm) & \\
\hline \multirow{2}{*}{$\mathrm{T}_{1}$ to $\mathrm{T}_{4}$} & Before levelling & 6.10 & -16 to 12 & Before sowing & 2.90 & -6 to 11 & \multirow{2}{*}{-75.40} \\
\hline & After levelling & 1.02 & -1 to 2 & After harvest & 4.60 & -10 to 11 & \\
\hline \multirow{2}{*}{$\mathrm{T}_{5}$} & Before levelling & 6.20 & -16 to 19 & Before sowing & 3.49 & -12 to 20 & \multirow{2}{*}{-87.25} \\
\hline & After levelling & 1.04 & -2 to1 & After harvest & 5.41 & -20 to 14 & \\
\hline \multirow{2}{*}{$\mathrm{T}_{6}$} & Before levelling & 6.11 & -9 to 13 & Before sowing & 4.32 & -9 to 5 & \multirow{2}{*}{+3.27} \\
\hline & After levelling & 4.00 & -8 to 8 & After harvest & 6.31 & -9 to 15 & \\
\hline \multirow{2}{*}{$\mathrm{T}_{7}$} & Before levelling & 6.33 & -9 to 13 & Before sowing & 4.72 & -8 to 9 & \multirow{2}{*}{+1.73} \\
\hline & After levelling & 3.44 & -6 to 7 & After harvest & 6.44 & -11 to 11 & \\
\hline
\end{tabular}

Note: - indicates reduction in LI and + indicates increase in LI. 
Fig.1 Diagram showing thematic flow chart of laser levelling concept

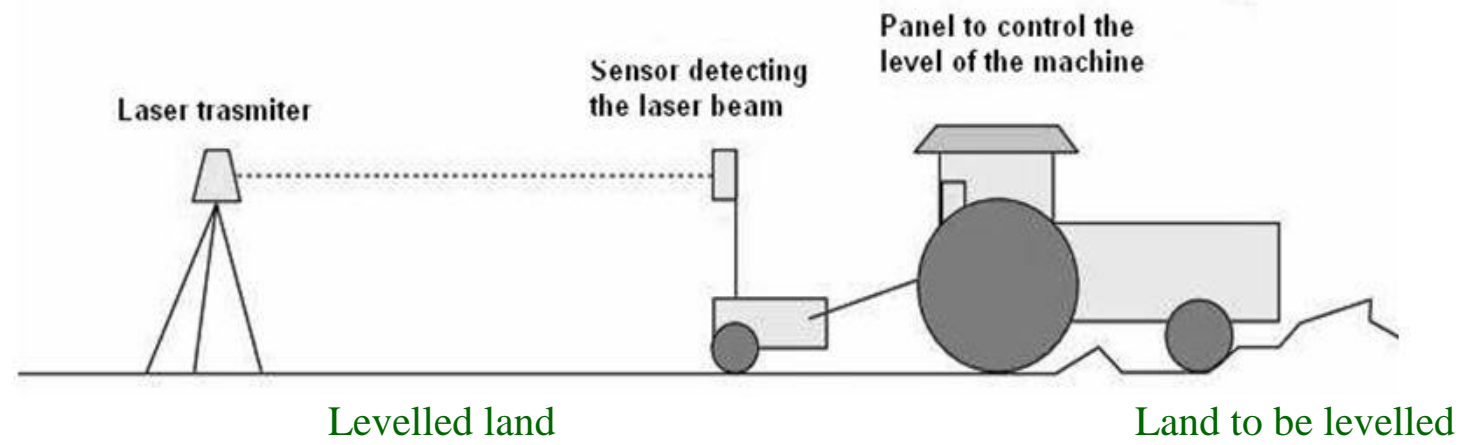

After the end of the experimental period i.e. during the year 2016, from the topographic variations as influenced by different land levelling, cultivation practices and irrigation methods in paddy, it was observed the levelling indices and range of grid elevations for treatments $\mathrm{T}_{1}$ to $\mathrm{T}_{4}$ were 4.60 and -10 to 11 $\mathrm{cm}$, for $\mathrm{T}_{5}$ were 5.41 and -20 to $14 \mathrm{~cm}$, for $\mathrm{T}_{6}$ were 6.31 and -9 to $15 \mathrm{~cm}$ and for $\mathrm{T}_{7}$ were 6.44 and -11 to $11 \mathrm{~cm}$, respectively. The data indicated that after the experiment period was over, the levelling quality again deteriorated due to weather conditions and cultivation practices. But the changes in topographic conditions were less in case of laser levelled plots as compared to traditional plots.

In paddy production, the levelling methods (Laser and Conventional), cultivation practices (DSR and TPR), irrigation methods (Drip and Flood) and also weather conditions effected the changes, in quality and precision of levelling in terms of LI and range of grid elevations, over the seasons. However, the data indicated the minimal changes in laser levelling cases $\left(T_{1}\right.$ to $T_{4}$ and $\left.T_{5}\right)$ as compared to $\mathrm{T}_{6}$ and $\mathrm{T}_{7}$. The $\%$ changes in levelling indices were as high as 75.40 and 87.25 in $\mathrm{T}_{1}$ to $\mathrm{T}_{4}$ and $\mathrm{T}_{5}$ indicating smaller changes in topographic conditions. Due to conventional levelling, in plots with flood irrigation and DSR and TPR methods of cultivation $\left(\mathrm{T}_{6}\right.$ and
$\mathrm{T}_{7}$ ), changes were higher with 3.27 and 1.73 per cent increase in LI, respectively. Likewise, the ranges of grid elevations after harvesting in the year 2016 changed from -16 to $12 \mathrm{~cm}$ to -10 to $11 \mathrm{~cm}$ for $T_{1}$ to $T_{4}$. In $T_{5}$ ranges of grid elevations changed from - 16 to $19 \mathrm{~cm}$ to -20 to $14 \mathrm{~cm}$. Ranges of grid elevations changed from -9 to $13 \mathrm{~cm}$ to -9 to $15 \mathrm{~cm}$ in $T_{6}$. Whereas, higher changes in range of grid elevations from -9 to $13 \mathrm{~cm}$ to 11 to $11 \mathrm{~cm}$ were found in treatment with Farmer's practice i.e., $\mathrm{T}_{7}$. The variability of levelling parameters viz., levelling index (LI), per cent reduction of LI and range of elevations of grid elevations in the field was very less in case of laser levelled fields indicating precise and accurate land levelling compared to traditional method (Xiang et al., 2000). The worst effects of variabilities were observed in unlevelled plot. It indicated the quality and levelness of the fields deteriorated over the time and space due to weather conditions and cultivation practices. But the changes in topographic conditions were very minimum in case of laser levelled fields as compared to traditional and unlevelled plots. This was evident from the smaller LI and range values. The similar findings were reported by Chaudhuri et al., (2007) and Shahin et al., (2013). The per cent changes were higher (75.40 and 87.25) in $\mathrm{T}_{1}$ to $\mathrm{T}_{4}$ and $\mathrm{T}_{5}$, whereas it was 3.27 in $\mathrm{T}_{6}$ plot. The control 
plot with farmers practice $\left(\mathrm{T}_{7}\right)$ had the worst effects on topographic conditions with +1.73 per cent. These findings corroborate with those observed by Suthakar et al., (2008), Kanannavar et al., (2012) and Anuraja et al., (2013). Laser levelling achieved high quality levelling which helped in making the land surface very much even leading to better irrigation performance as inferred by Subramani and Martin (2011).

Laser land levelling and drip irrigation techniques used for paddy cultivation were observed to facilitate development of agricultural land scientifically to a desired grade with more ease leading to improved irrigation and higher water use efficiencies indicating more production with less irrigation water over traditional levelling and flood irrigation method. Smaller values of LI and range of topographic elevations indicated higher accuracy of grading in laser levelled fields with evenly levelled field and uniform distribution of water and its storage.

\section{Acknowledgements}

Authors are grateful to staff and Dean of College of Agricultural Engineering, UAS Raichur for their support and providing Laser leveller unit for the study and CIMMYT, New Delhi and Dean (PGS) of UAS Raichur for their help in successful completion of study. Thanks are also to farmer Sri. Suresh Reddy who spared his land for drip irrigation studies in paddy.

\section{References}

Agarwal, M. C. and Goel, A. C., 1981, Effect of field levelling quality on irrigation efficiency and crop yield. J. Agric. Water Mgt., 4: 457-464.

Anuraja, B., Kanannavar, P. S., Balakrishnan, P., Pujari, B. T. and Hadimani, M. B., 2013, Laser guided land leveller for precision land development. Karnataka J. Agric. Sci., 26 (2): 271-275.

Chaudhuri, D., Mathankar, S. K., Singh, V. V., Shirsat, N. A. and Dubey, U. C., 2007, Performance evaluation of laser guided land leveller in vertisols of central India. J. Agric. Engg., 44(2):1-6.

Shahin, A., Jafar, H. and Seyed, M. J. A., 2013, Levelling as a tool for reducing water casualties in wheat fields. Int. J. Agric. Crop Sci., 6(6): 296-299.

Subramani, J. and Martin, E. C., 2011, Effects of yearly laser levelling on yield and irrigation: a large scale demonstration. Arizona Cotton Rep., p.159.

Suthakar, B., Kathrivel, K., Manian, R. and Manohar Jesudas., 2008, Laser guided land leveller: precision leveller with laser technology for land preparation. $J$. Agric. Mech. in Asia, Africa, Latin America. 39(4): 30-36.

Xiang Lu., Nong Fu., Di Xu and Li Yi, 2000, Effectiveness evaluation and combined application of land levelling techniques. Trans. Chinese Soc. Agric. Engg., 16 (2): 50-53.

\section{How to cite this article:}

Ravindra Yaligar, P. Balakrishnan, U. Satishkumar, P. S. Kanannavar, A. S. Halepyati, M. L. Jat and Rajesh N. L. 2017. Land Levelling and Its Temporal Variability under Different Levelling, Cultivation Practices and Irrigation Methods for Paddy. Int.J.Curr.Microbiol.App.Sci. 6(9): 3784-3789. doi: https://doi.org/10.20546/ijcmas.2017.609.467 